\title{
High frequency of promoter methylation of the 14-3-3 o and CAGE-1 genes, but lack of hypermethylation of the caveolin-1 gene, in primary adenocarcinomas and signet ring cell carcinomas of the urinary bladder
}

\author{
EKKEHARD KUNZE and THILO SCHLOTT \\ Department of Osteopathology and Haematopathology, Georg-August-University of Göttingen, Göttingen, Germany
}

Received April 24, 2007; Accepted June 14, 2007

\begin{abstract}
The molecular mechanisms underlying the histogenesis of nonurothelial carcinomas of the urinary bladder are not yet clearly understood. There is a growing body of evidence that, generally, epigenetic regulation mediated by methylation of normally unmethylated $\mathrm{CpG}$ islands at the $5^{\prime}$ promoter regions of genes is involved in the modification of tumorigenesis. This prompted the current study to explore the methylation status of a broad panel of various genes implicated in cell differentiation and tumor suppression in 10 adenocarcinomas and 6 signet ring cell carcinomas of the bladder. Using methylation-specific PCR, we were able to detect a high frequency of promoter methylation of the 14-3-3 $\sigma(100 \%)$ and CAGE-1 (80\%) genes in adenocarcinomas, and in nearly all signet ring cell carcinomas. The SYK and hDAB2IP genes proved to be hypermethylated in only single cases, whereas the caveolin-1 gene failed to be hypermethylated in all cases. The present data suggest that promoter methylation of the 143-3 $\sigma$ and CAGE-1 genes plays a crucial role during the phenotypical morphogenesis of vesical adenocarcinomas including signet ring cell carcinomas by an epigenetic mechanism.
\end{abstract}

\section{Introduction}

Primary nonurachal adenocarcinomas and particularly signet ring cell carcinomas of the urinary bladder are rare and are reported to account for $0.5-2 \%$ of all vesical cancers. At first glance, the morphogenesis of adenocarcinomas appears difficult to understand since the urinary bladder is normally lined exclusively by transitional cell epithelium, but there is strong evidence that they develop by a metaplastic

Correspondence to: Dr E. Kunze, Department of Osteopathology and Haematopathology, University of Göttingen, Robert-Koch-Str. 40, D-37099 Göttingen, Germany

E-mail: ekunze@med.uni-goettingen.de

Key words: urinary bladder, adenocarcinomas, signet ring cell carcinomas, promoter methylation, 14-3-3 $\sigma$, CAGE-1, SYK, hDAB2IP, caveolin-1 transformation of the urothelium. The well known inherent potential of urothelial cells to convert to other cell types (1) can best be explained by the embryologic origin of the urinary bladder from the cloacal endoderm (dome and median regions) and the Wolffian ducts (trigone), the pluripotent epithelia of which are capable of differentiating in several directions resulting in different cellular phenotypes. Adenocarcinomas may develop either primarily from a columnar or glandular metaplasia (cystitis glandularis of the intestinal type) of the transitional cell epithelium following malignant transformation (2,3, reviewed in ref. 4) or, more commonly, secondarily from pre-existent transitional cell carcinomas (TCC) via a glandular metaplasia of the neoplastic urothelial cells (4-6).

The signalling pathways leading to the development of vesical adenocarcinomas are not clearly understood. An abnormal protein production may be implicated since adenocarcinomas and signet ring cell carcinomas differ from TCC, squamous cell and undifferentiated small cell carcinomas by their protein expression. In favor of this are our previous immunohistochemical studies documenting, for example, a neoexpression or reexpression, respectively, of the MUC5A apomucin (6-8) and of the trefoil peptide pS2 (8) in a high percentage of adenocarcinomas including signet ring cell carcinomas, as distinguished from common TCC and other nonurothelial cancers which fail to synthesize these proteins.

As a possible molecular mechanism underlying the divergent protein expression, it is hypothesized that epigenetic events may play a role, mediated by methylation of normally unmethylated cytosine dinucleotides at the 5 ' promoter regions. This is supported by our recent findings yielding different frequencies of aberrant methylation of several genes in TCC, squamous cell carcinomas and undifferentiated small cell carcinomas $(9,10)$. In continuation of our previous studies, we now explored the methylation status of a panel of genes implicated in cell differentiation or functioning as known or putative tumor suppressors in adenocarcinomas including signet ring cell carcinomas. Using methylation-specific PCR, we were able to detect for the first time a high rate of promoter methylation of the 14-3-3 $\sigma$ and CAGE-1 genes, indicating that these genes are significantly involved during the histogenesis of vesical adenocarcinomas, while the caveolin- 1 gene totally lacked hypermethylation. 


\section{Materials and methods}

Specimens. In this study we analysed archival formalin-fixed and paraffin-embedded samples of 7 primary pure adenocarcinomas, 3 adenocarcinomas within pre-existent transitional cell carcinomas (TCC), and 6 signet ring cell carcinomas (4 pure forms and 2 admixed to TCC) of the urinary bladder. The tumor samples were obtained from patients who had undergone transurethral resection or radical cystectomy. Five probes of normal, nonneoplastic bladder mucosa from cystectomy specimens served as the controls.

Molecular pathological assays. For molecular genetic analysis, histological sections, $5 \mu \mathrm{m}$ in thickness, were prepared from the paraffin-embedded samples. Following identification of the cancer tissue in a section stained with haemalum and eosin, between 10 and 15 consecutive sections were prepared for the molecular pathological assays and were not stained. To assure that all of these sections contained cancer tissue, the last was stained with haemalum and eosin and examined microscopically. The tumor tissue was separated from nonneoplastic tissues and scraped from the sections with a razor blade. Similarly, the foci of adenocarcinomas within TCC were carefully excised.

DNA extraction and $\beta$-globin PCR. DNA was extracted from the cancer tissues with the QIAamp DNA minikit (Qiagen, Hilden, Germany) according to the manufacturer's instructions. The DNA, diluted in $500 \mathrm{ml}$ bidistilled water, was mixed with $500 \mu 1$ isopropanol and incubated for $60 \mathrm{~min}$ at room temperature. The precipitated DNA was collected by centrifuging the solution for $60 \mathrm{~min}$ at 14,000 x g (Heraeus Biofuge 15, Osterode/Harz, Germany) and washed with $100 \mu 1$ ethanol (96\%). The tubes were incubated without lids at room temperature for $10 \mathrm{~min}$. Thereafter, the DNA pellets were dissolved in $10 \mu \mathrm{l}$ bidistilled water at $50^{\circ} \mathrm{C}$ for $10 \mathrm{~min}$. A quantity of $0.5 \mu$ l DNA was diluted 1:100 in bidistilled water and used for B-globin PCR. Primers were sense, 5'-CTT CTG ACA CAA CTG TGT TCA CT-3' and anti-sense, 5'-TCA CCA CCA ACT TCA TCC ACG T-3' (product size 123 bp). PCR was performed at a total volume of $50 \mu 1$ in a Primus-25 DNA thermocycler (MWG, Ebersberg, Germany). Each reaction mixture contained $200 \mathrm{ng}$ DNA, $10 \mathrm{pmol}$ of each sense and anti-sense primer, $4 \mu \mathrm{l}$ dNTPs (10 mM each), $5 \mu 1$ of $10 \mathrm{X}$ reaction buffer [Tris-HCI ( $\mathrm{pH} \mathrm{8.7),} \mathrm{KCI},\left(\mathrm{NH}_{4}\right)_{2} \mathrm{SO}_{4}$, $15 \mathrm{mM} \mathrm{MgCI}_{2}$ ], and 1 unit HotStarTaq polymerase (Qiagen, Germany). The thermal cycling conditions consisted of an initial 15 -min step at $95^{\circ} \mathrm{C}$ to denaturate the DNA and to activate the HotStarTaq DNA polymerase. The DNA obtained was amplified by 40 cycles $\left(95^{\circ} \mathrm{C}\right.$ for $30 \mathrm{sec}, 55^{\circ} \mathrm{C}$ for $60 \mathrm{sec}$, and $72^{\circ} \mathrm{C}$ for $60 \mathrm{sec}$ ). The cycling protocol was completed with a 7-min step at $72^{\circ} \mathrm{C}$ to prevent incomplete synthesis of PCR products. The PCR fragments obtained were separated on a $3 \%$ agarose gel stained with ethidium bromide $(5 \mu \mathrm{l} /$ $40 \mathrm{ml}$ agarose).

Methylation-specific PCR. DNA isolated from tumor samples ( $1 \mu \mathrm{g})$ was treated with sodium bisulfite using the CpGenome DNA modification kit (Intergen Co., Oxford, UK) according to the manufacturer's instructions. Modified

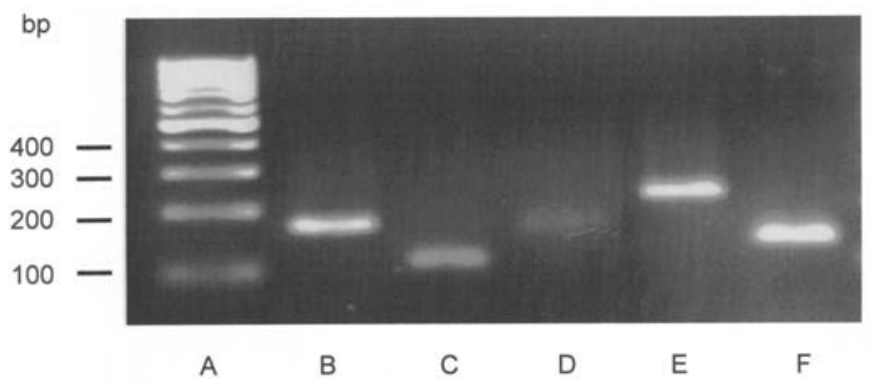

Figure 1. Analysis of PCR products amplified by methylation-specific PCR. The fragments were separated on $3 \%$ agarose gel. Lane A shows molecular weight standard; lanes B, C, D, E, and F show hDAB2IP, 14-3-3 o, SYK, Caveolin-1, and CAGE-1 products, respectively. Data document the correct lengths of the gene promoter-specific fragments produced.

DNA ( $2 \mu 1,1 / 5$ volume) was used for PCR amplification. The primers for analysing the various genes were the following. 14-3-3 $\sigma(11)$ : for methylated sequences, sense 5'TGG TAG TTT TTA TGA AAG GCG TC-3' and anti-sense 5'-CCT CTA ACC GCC CAC CAC G-3' (product size 105 bp); for unmethylated sequences, sense 5'-ATG GTA GTT TTT ATG AAA GGT GTT-3' and anti-sense 5'-CCC TCT AAC CAC CCA CCA CA-3' (product size 107 bp). SYK (12): for methylated sequences, sense 5'-CGA TTT CGC GGG TTT CGT TC-3' and anti-sense 5'-AAA ACG AAC GCA ACG CGA AAC-3' (product size $140 \mathrm{bp}$ ); for unmethylated sequences, sense 5'-ATT TTG TGG GTT TTG TTT GGT G3' and anti-sense 5'-ACT TCC TTA ACA CAC CCA AAC-3' (product size $243 \mathrm{bp}$ ). CAGE-1 (13): for methylated sequences, sense 5'-TTT TAT ACG ATT CGG AAT TCG AC-3' and anti-sense 5'-CAA ATC TAC GAC CTA TTT CCC G-3' (product size $150 \mathrm{bp}$ ); for unmethylated sequences, sense 5'-GTT TTT TAT ATG ATT TGG AAT TTG AT-3' and anti-sense 5'-AAT TCA AAT CTA CAA CCT ATT TCC CA (product size $150 \mathrm{bp}$ ). Caveolin-1 (14): for methylated sequences, sense 5'-GGT ATT TTT GTA GGC GCG TC-3' and anti-sense 5'-CTA ACA AAA AAC GAA AAA CG-3' (product size $174 \mathrm{bp}$ ); for unmethylated sequences, sense 5'GTT TAT ATT GGG TAT TTT TGT AGG TGT GT-3' and anti-sense 5'-TCC CCA AAA TTC TAA CAA CAA AAA ACA AAA AAC-3' (product size 174 bp). hDAB2IP (15): for methylated sequences, sense 5'-GAG GTG AGC GGG GCG GTC-3' and anti-sense 5'-CGC TAT TAC CTT AAC GAC GCC GA-3' (product size 163 bp); for unmethylated sequences, sense 5'-ATT TAC GGT ATT AGC GGG GTG GTT-3' and anti-sense 5'-CAC TAT TAC CTT AAC AAC ACC AA-3' (product size 163 bp).

PCR was performed at a total volume of $50 \mu 1$ using a Primus-25 thermocycler. Each reaction mixture contained $200 \mathrm{ng}$ template, $20 \mathrm{pmol}$ of each sense and anti-sense primer, $4 \mu 1 \mathrm{dNTP}$ 's (200 mM each), $5 \mu 1$ 10X reaction buffer [Tris-HCI (pH 8.7), KCI, $\left(\mathrm{NH}_{4}\right)_{2} \mathrm{SO}_{4}, 15 \mathrm{mM} \mathrm{MgCI}{ }_{2}$, and 1 unit HotStarTaq DNA polymerase. The thermocycling conditions consisted of an initial 15 -min step at $95^{\circ} \mathrm{C}$ to denaturate the DNA and to activate the HotStarTaq DNA polymerase. Further amplification conditions for the various methylated and unmethylated genes were as follows. 14-3-3 $\sigma$, methylated and unmethylated: 45 cycles $\left(95^{\circ} \mathrm{C}\right.$ for $45 \mathrm{sec}$, 


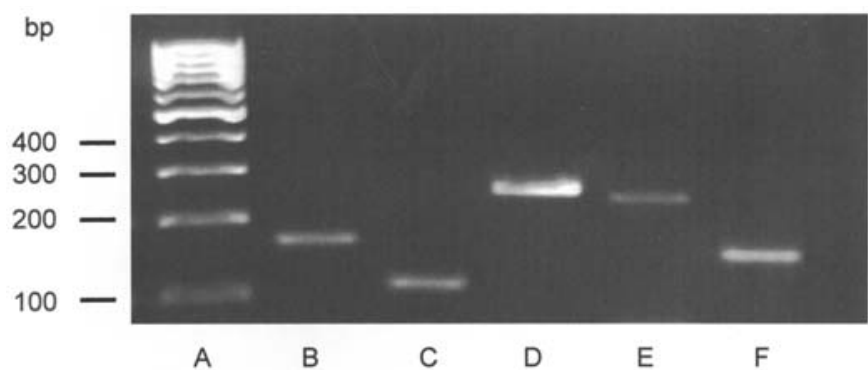

Figure 2. Analyses of PCR products amplified by nonmethylation-specific PCR. The fragments were separated on $3 \%$ agarose gel. Lane A shows molecular weight standard; lanes B, C, D, E, and F show hDAB2IP, 14-3-3 o, SYK, Caveolin-1, and CAGE-1 products, respectively. Data document the correct lengths of the gene promoter-specific fragments produced.

$56^{\circ} \mathrm{C}$ for $30 \mathrm{sec}, 72^{\circ} \mathrm{C}$ for $\left.30 \mathrm{sec}\right)$; SYK, methylated and unmethylated: 45 cycles $\left(94^{\circ} \mathrm{C}\right.$ for $45 \mathrm{sec}, 60^{\circ} \mathrm{C}$ for $45 \mathrm{sec}$, $72^{\circ} \mathrm{C}$ for $\left.60 \mathrm{sec}\right)$; CAGE-1, methylated and unmethylated: 45 cycles $\left(94^{\circ} \mathrm{C}\right.$ for $30 \mathrm{sec}, 57^{\circ} \mathrm{C}$ for $30 \mathrm{sec}, 72^{\circ} \mathrm{C}$ for $\left.60 \mathrm{sec}\right)$; caveolin-1, methylated and unmethylated: 45 cycles $\left(94^{\circ} \mathrm{C}\right.$ for $30 \mathrm{sec}, 57^{\circ} \mathrm{C}$ for $30 \mathrm{sec}, 72^{\circ} \mathrm{C}$ for $\left.60 \mathrm{sec}\right)$; hDAB2IP, methylated: 45 cycles $\left(94^{\circ} \mathrm{C}\right.$ for $20 \mathrm{sec}, 61^{\circ} \mathrm{C}$ for $30 \mathrm{sec}, 72^{\circ} \mathrm{C}$ for $30 \mathrm{sec})$ and unmethylated: 45 cycles $\left(94^{\circ} \mathrm{C}\right.$ for $20 \mathrm{sec}$, $50^{\circ} \mathrm{C}$ for $30 \mathrm{sec}, 72^{\circ} \mathrm{C}$ for $\left.30 \mathrm{sec}\right)$. Each of the cycling protocols was completed with a final extension step at $72^{\circ} \mathrm{C}$ for $7 \mathrm{~min}$. Following amplification, the PCR fragments were separated on a $3 \%$ agarose gel stained with ethidium bromide ( $5 \mu 1 / 40 \mathrm{ml}$ agarose). Examples of methylated promoter sequences are demonstrated in Figs. 1 and 2.

\section{Results}

Methylation status of the normal bladder mucosa. All five probes of normal bladder mucosa lacked promoter methylation of the caveolin-1, SYK and hDAB2IP genes. Two showed hypermethylation of the 14-3-3 $\sigma$ and one of the CAGE-1 gene; in our previous study an aberrant methylation of both these genes was not observed (10).

Promoter methylation of adenocarcinomas. The frequency of promoter methylation of the adenocarcinomas is listed in Table I. All 10 cancers analysed disclosed a hypermethylation of the $14-3-3 \sigma$ gene $(100 \%)$ and $80 \%$ revealed a methylation at the promoter region of the CAGE-1 gene. Both the hDAB2IP and the SYK genes proved to be hypermethylated in only single cases. The caveolin-1 gene totally lacked DNA hypermethylation. However, the method used was not suitable for quantifying the total extent of methylation of the binding sequences and the amplified product. This would have required a sequence analysis.

Promoter methylation of signet ring cell carcinomas. Signet ring cell carcinomas showed a methylation pattern identical with that determined in adenocarcinomas (Table II). The 14-3-3 $\sigma$ gene was hypermethylated in all six and the CAGE-1 gene in five (83\%) tumors. Only one case revealed a promoter methylation of each of the hDAB2IP and SYK genes.

\section{Discussion}

There is a growing body of evidence that epigenetic gene regulation, mediated by methylation of normally unmethylated $\mathrm{CpG}$ islands at promoter sites, plays a crucial role in modifying tumorigenesis (reviewed in refs. 16-19). Our previous studies yielded a substantially different frequency of promoter methylation of the 14-3-3 o, caveolin-1 and SYK genes in transitional cell carcinomas (TCC), squamous cell carcinomas and undifferentiated small cell carcinomas of the urinary bladder $(9,10)$. These findings prompted the current investigation to analyse the methylation status of a panel of genes

Table I. Frequency of promoter methylation of various genes in adenocarcinomas of the urinary bladder $(+$ promoter methylation present, - promoter methylation absent). ${ }^{\mathrm{a}}$

\begin{tabular}{|c|c|c|c|c|c|}
\hline \multirow[b]{2}{*}{ Case no. } & \multicolumn{5}{|c|}{ Methylation status } \\
\hline & $14-3-3 \sigma$ & CAGE-1 & SYK & hDAB2IP & Caveolin-1 \\
\hline 1 & + & + & - & - & - \\
\hline 2 & + & - & - & - & - \\
\hline 3 & + & + & - & - & - \\
\hline 4 & + & + & + & + & - \\
\hline 5 & + & - & - & - & - \\
\hline 6 & + & + & - & - & - \\
\hline 7 & + & + & - & - & - \\
\hline 8 & + & + & - & - & - \\
\hline 9 & + & + & - & - & - \\
\hline 10 & + & + & - & + & - \\
\hline $\begin{array}{l}\text { Rate of } \\
\text { hypermethylation }\end{array}$ & $\begin{array}{c}10 / 10 \\
(100 \%)\end{array}$ & $\begin{array}{c}10 / 8 \\
(80 \%)\end{array}$ & $\begin{array}{c}10 / 1 \\
(10 \%)\end{array}$ & $\begin{array}{c}10 / 2 \\
(20 \%)\end{array}$ & $\begin{array}{l}10 / 0 \\
(0 \%)\end{array}$ \\
\hline
\end{tabular}

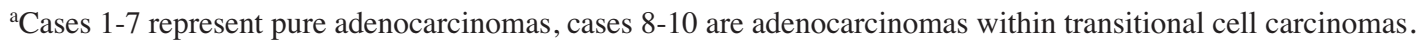


Table II. Frequency of promoter methylation of various genes in signet ring cell carcinomas of the urinary bladder (+ promoter methylation present, - promoter methylation absent). ${ }^{\mathrm{a}}$

\begin{tabular}{|c|c|c|c|c|c|}
\hline \multirow[b]{2}{*}{ Case no. } & \multicolumn{5}{|c|}{ Methylation status } \\
\hline & $14-3-3 \sigma$ & CAGE-1 & SYK & hDAB2IP & Caveolin-1 \\
\hline 1 & + & + & - & - & - \\
\hline 2 & + & + & - & - & - \\
\hline 3 & + & + & + & - & - \\
\hline 4 & + & - & - & + & - \\
\hline 5 & + & + & - & - & - \\
\hline 6 & + & + & - & - & - \\
\hline Rate of & $6 / 6$ & $6 / 5$ & $6 / 1$ & $6 / 1$ & $6 / 0$ \\
\hline hypermethylation & $(100 \%)$ & $(83 \%)$ & $(17 \%)$ & $(17 \%)$ & $(0 \%)$ \\
\hline
\end{tabular}

${ }^{a}$ Cases 1-4 represent pure signet ring cell carcinomas, cases 5 and 6 signet ring cell carcinomas within transitional cell carcinomas.

involved in cell differentiation or acting as known or putative tumor suppressors in adenocarcinomas and signet ring cell carcinomas. Among the various genes examined, the 14-3-3 $\sigma$ and CAGE-1 genes were identified as critical targets in the morphogenesis of adenocarcinomas as suggested by a high rate of hypermethylation.

Methylation status of the 14-3-3 o gene. The 14-3-3 $\sigma$ gene is activated by the tumor suppressor gene p53 and is involved in cell cycle regulation by arresting proliferating cells at the transition from the $\mathrm{G} 2$ phase to the mitotic phase (G2 check point), allowing repair of DNA damage caused, for example, by ionising radiation (20). The underlying mechanism consists in sequestering the protein kinase cdc2 and the cyclin B1 complex that triggers progession of cells through the G2 phase and initiates mitosis (21-23). The 14-3-3 $\sigma$ gene encodes for a protein named stratifin or HME1 that induces terminal differentiation of keratinocytes and was initially observed to be strongly expressed in stratified squamous epithelium $(21,24,25)$

All adenocarcinomas and signet ring cell carcinomas showed a methylation of the promoter region of the 14-3-3 $\sigma$ gene. This is the highest frequency of methylation of 14-3-3 $\sigma$ which we could determine among the various histopathological types of bladder cancers (10). Squamous cell carcinomas were aberrantly hypermethylated in $80 \%$, highgrade, high-stage TCC in $57.1 \%$, and low-grade, low-stage TCC as well as undifferentiated small cell carcinomas in only a quarter of the cases. These data point to a correlation between the methylation status of the 14-3-3 $\sigma$ gene and tumor cell differentiation, assumed to be responsible for the formation of the various phenotypic cancer types, particularly of adenocarcinomas.

Immunohistochemically, all signet ring cell carcinomas and more than half of the adenocarcinomas showed a total loss of 14-3-3 protein expression. The majority of the remaining cases revealed only a heterogeneous, patchy immunoreactivity (8). These findings are compatible with a transcriptional gene deregulation or silencing, respectively, as a result of the aberrant methylation. Such a relationship could not be verified in squamous cell carcinomas exhibiting a high rate of promoter methylation (80\%) of the 14-3-3 $\sigma$ gene but a strong diffuse protein expression (100\%) and did not exist in undifferentiated small cell cancers which disclosed a low frequency of hypermethylation (25\%) and a suppressed heterogeneous or lacking expression (10).

Aberrant methylation of the 14-3-3 $\sigma$ gene also plays a prominent role in cancers in organs other than the urinary bladder. Invasive ductal carcinomas of the breast were reported to be hypermethylated between 86 and $96 \%(11,26)$, hepatocellular carcinomas in $89 \%$ (27), gastric cancers in $43 \%$ (28) and oral carcinomas in 35\% (29) of the cases. The significance of promoter methylation of the 14-3-3 $\sigma$ gene in modulating phenotypical tumor cell differentiation resulting in the development of different histopathological tumor types is supported by findings in ovarian cancers; clear cell carcinomas displayed a considerably higher frequency of promoter methylation $(78.6 \%)$ than mucinous (36.4\%), serous (26.3\%) and endometrioid (20.0\%) adenocarcinomas (30).

Methylation status of the CAGE-1 gene. The cancer/testis (CT) antigen gene CAGE-1 was originally identified by SEREX analysis (serological analysis of recombinant tumor cDNA expression libraries with autologous serum) of sera from patients with gastric cancers (reviewed in refs. 31-33). This gene belongs to a large family of closely related CT genes including the MAGE multigene family and the NYESO-1 gene which are mapped to the $\mathrm{X}$ chromosome. They encode autoimmunogenic tumor-associated antigens, capable of triggering a tumoral immune response (reviewed in ref. 32). The protein expression of the CT genes including CAGE- 1 is normally restricted to the testis, but aberrantly expressed in a wide variety of human malignant tumors (31-35).

Nearly all adenocarcinomas and signet ring cell carcinomas were found to be methylated at the promoter region of the CAGE-1 gene, indicating that the epigenetic alteration of this gene plays a crucial role during the morphogenesis of vesical adenocarcinomas. Among the other histological bladder cancer types previously examined, TCC proved to be hyper- 
methylated in $64.3 \%$ independent of their grades and stages, squamous cell carcinomas in $53.3 \%$, and undifferentiated small cell carcinomas in $25 \%$ (10). The only other study exploring the methylation status of various malignant tumors yielded hypomethylation at a rate of $>60 \%$ in breast, gastric, lung and hepatocellular carcinomas, and at a lower frequency $(<40 \%)$ in prostate, uterine, cervical and laryngeal cancers (16). The significance of DNA hypomethylation remains to be unveiled, however, there is evidence that it may promote tumorigenesis by causing chromosomal instability $(36,37)$.

From a clinical and therapeutic point of view, the CT antigens are discussed as potential targets of an antibody-based anticancer immunotherapy (reviewed in ref. 32). However, the development of effective immunization strategies appears problematic, since the production of immunogenic proteins varied considerably in the individual tumors $(35,38)$, and seropositivity occurred only in a minority of cases (35).

Methylation status of the caveolin-1 gene. The caveolin-1 gene codes for a 21-to 24-kDa protein that is a major integral component of caveolae. They represent vesicular invaginations of the plasma membrane and occur in many cell types (reviewed in ref. 39). The caveolin scaffolding protein contains glycophospholipid-rich microdomains, mediates molecular transport, regulates various signalling pathways including Src family tyrosine kinases, epidermal growth factor receptor, transforming growth factor, nitric oxide synthase and cyclin D1 pathways (reviewed in ref. 39).

None of the adenocarcinomas and signet ring cell carcinomas proved to be methylated at the promoter site of the caveolin-1 gene, providing evidence that epigenetic control of this gene is not involved at all in the histogenesis of adenocarcinomas. This is supported by the fact that neither adenocarcinomas nor normal transitional cell epithelium synthesize the protein as determined by immunohistochemistry (9). TCC also lacked DNA hypermethylation, whereas half of undifferentiated small cell and a quarter of squamous cell carcinomas were characterised by an aberrant methylation (8). The different frequency of promoter methylation in the various phenotypical cancer types point to a differential role of the caveolin-1 gene in bladder carcinogenesis, possibly as a result of activation or inactivation of different domains of the gene.

The significance of the caveolin-1 gene in tumorigenesis is suggested by immunohistochemical findings obtained in various other human cancers. A protein overexpression has been reported, for example, in pancreatic ductal adenocarcinomas (40), renal cell carcinomas (41), prostate cancer (42), lung cancer (43) and adenocarcinomas of the colon (44). Overexpression was correlated with higher pathological stages, an increased incidence of lymph node metastasis and a poorer prognosis. The significance of the caveolin gene in tumor cell differentiation as observed in bladder carcinogenesis (9) is supported by immunohistochemical findings obtained in other carcinomas. Undifferentiated carcinomas, follicular carcinomas and adenomas of the thyroid failed to express the protein, while papillary cancers were found to be immunopositive (45). Ovarian serous adenomas expressed the caveolin gene, serous and endometrioid carcinomas showed substantially lower expression levels compared to the normal ovarian surface epithelium, and mucinous adenomas as well as mucinous carcinomas stained negatively (46).

Methylation status of the SYK gene. The SYK gene is located on chromosome 9 at band q22, contains two Src homology 2 (SH2) domains in tandem and C-terminal kinase domains, and encodes for the non-receptor type of protein-tyrosine kinase (reviewed in ref. 47). The SYK family is involved in the development and activation of B- and T-lymphocytes by immunoreceptor signalling pathways and regulates haematopoietic cell functions. The SYK protein-tyrosine kinase is, moreover, implicated in signal transduction pathways of nonhaematopoietic cells and is likely to function as a tumor suppressor (reviewed in ref. 47).

We detected only single cases of adenocarcinomas and signet ring cell carcinomas with methylated $\mathrm{CpG}$ islands of the SYK gene. This finding together with our previous observations that undifferentiated small cell carcinomas $(25 \%)$ and squamous cell cancers $(13.3 \%)$ disclosed a low rate of DNA hypermethylation (10) argue against a substantial role of promoter methylation of the SYK gene during the morphogenesis of nonurothelial bladder carcinomas, particularly of adenocarcinomas including signet ring cell carcinomas. By contrast, superficial low-grade TCC were hypermethylated in $42.9 \%$ and muscle-invasive high-grade TCC in $64.3 \%$ of the cases (10), providing evidence that aberrant methylation is associated with progression of TCC from a low to a high malignant potential. This is supported by a total loss of immunohistochemical protein expression in half of the high-grade muscle-invasive TCC, while $78.6 \%$ of the low-grade superficial TCC showed a diffuse moderate or strong and the remaining cases a weak immunoreactivity, but not a total loss of expression (10). Taken together, these findings suggest that DNA hypermethylation impedes binding of the transcriptional factors, causing downregulation or silencing of the SYK gene activity. The significance of the SYK gene as a tumor suppressor is apparent from findings obtained in cancers of organs other than the urinary bladder. Cancers of the breast were reported to be hypermethylated in $32 \%$ (48) and gastric cancers in $34.4 \%$ (12) of the cases, coinciding with a higher incidence of lymph node metastases.

Methylation status of the hDAB2IP gene. The hDAB2IP gene maps to chromosome 9q33.1-q33.3 and produces a GTPaseactivating protein. hDAB2IP forms a complex with DOC-2/ DAB2 which contains a phosphotyrosine domain and multiple C-terminal proline-rich SH3-binding domains interacting with the Grb2 adapter protein $(49,50)$. It is assumed that the hDAB2IP gene acts as a tumor suppressor by negatively regulating cell growth via downregulation of Rascontrolled signal pathways.

The observed low rate of promoter hypermethylation of the hDAB2IP gene indicates that epigenetic control of this gene does not play a substantial role in the pathogenesis of adenocarcinomas and signet ring cell carcinomas, as opposed to TCC and the other nonurothelial cancer types. The highest frequency of DNA hypermethylation was determined (9) in high-grade, high-stage TCC $(72.7 \%)$ followed by low-grade, low-stage TCC (50\%), undifferentiated small cell carcinomas (50\%), and squamous cell carcinomas $(48.1 \%)$. The signifi- 
cance of aberrant methylation of the hDAB2IP gene has been evidenced in some other cancers, as for example, in breast carcinomas (15) and lung cancers (51) which were reported to be hypermethylated in approximately one-third of the cases. A repressed mRNA expression of disabled-2 in human prostate cancer cell lines $(52,53)$ and a decreased or even lacking protein expression in ovarian cancers (54) support the view that hDAB2IP represents a tumor suppressor, the function of which appears abrogated by methylation of the CpG sites (53).

In conclusion, a high frequency of promoter methylation of the 14-3-3 $\sigma$ and CAGE-1 genes suggests that epigenetic deregulation of these genes are involved in the morphogenesis of adenocarcinomas and signet ring cell carcinomas of the urinary bladder. The low rate of aberrant methylation of the SYK and hDAB2IP genes argues against a substantial role in the phenotypical development of adenocarcinomas. The caveolin- 1 gene proved not to be implicated at all, since none of the carcinomas were hypermethylated.

\section{Acknowledgements}

The authors wish to thank Maike Wendt for the excellent technical processing.

\section{References}

1. Mostofi FK: Potentialities of bladder epithelium. J Urol 71: 705-714, 1954.

2. Edwards PD, Hurm RA and Jaeschke WH: Conversion of cystitis glandulatis to adenocarcinoma. J Urol 108: 568-570, 1972.

3. Bullock PS, Thoni DE and Murphy WM: The significance of colonic mucosa (intestinal metaplasia) involving the urinary tract. Cancer 59: 2086-2090, 1987.

4. Kunze E: Formale Pathogenese des Harnblasenkarzinoms. In: Diagnostik und Therapie des Harnblasenkarzinoms. Bichler KH, Wilbert D, Wechsel HW and Strohmaier WS (eds). EinhornPresse Verlag, Reinbeck, pp14-42, 1998.

5. Kunze E: Histogenesis of nonurothelial carcinomas in the human and rat urinary bladder. Exp Toxicol Pathol 50: 341-355, 1998.

6. Kunze E and Francksen B: Histogenesis of nonurothelial carcinomas of the urinary bladder from pre-existent transitional cell carcinomas. A histopathological and immunohistochemical study. Urol Res 30: 66-78, 2002.

7. Kunze E, Francksen B and Schulz H: Expression of MUC5AC apomucin in transitional cell carcinomas of the urinary bladder and its possible role in the development of mucus-secreting adenocarcinomas. Virchows Arch 439: 609-615, 2001.

8. Kunze E, Krassenkova I and Fayyazi A: Tumor-associated neoexpression of the $\mathrm{pS} 2$ peptide and MUC5AC mucin in primary adenocarcinomas and signet ring cell carcinomas of the urinary bladder. Histol Histopathol (In press).

9. Kunze E, von Bonin F, Werner C, Wendt M and Schlott T: Transitional cell carcinomas and nonurothelial carcinomas of the urinary bladder differ in the promoter methylation status of the caveolin-1, hDAB2IP and p53 genes, but not in the global methylation of Alu elements. Int J Mol Med 17: 3-13, 2006.

10. Kunze E, Wendt M and Schlott T: Promoter hypermethylation of the 14-3-3 $\sigma$, SYK and CAGE-1 genes is related to the various phenotypes of urinary bladder carcinomas and associated with progression of transitional cell carcinomas. Int J Mol Med 18: 547-557, 2006.

11. Ferguson AT, Evron E, Umbricht CB, Pandita TK, Chan TA, Hermeking H, Marks JR, Lambers AR, Futreal PA, Stampfer MR and Sukumar S: High frequency of hypermethylation at the 143-3 sigma locus leads to gene silencing in breast cancer. Proc Natl Acad Sci USA 97: 6049-6054, 2000.

12. Wang S, Ding YB, Chen GY, Xia JG and Wu ZY: Hypermethylation of Syk gene in promoter region associated with oncogenesis and metastasis of gastric carcinoma. World J Gastroenterol 10: 1815-1818, 2004.
13. Cho B, Lee H, Jeong SW, Bang YJ, Lee HJ, Hwang KS, Kim HY, Lee YS, Kang GH and Jeong DI: Promoter hypomethylation of a novel cancer/testis antigen gene CAGE is correlated with its aberrant expression and is seen in premalignant stage of gastric carcinoma. Biochem Biophys Res Commun 307: 52-63, 2003.

14. Chen T-F, Su T-H, Yeh K-T, Chang J-Y, Lin T-H, Chen J-C, Yuang S-S and Chang J-G: Mutational, epigenetic and expressional analyses of caveolin-1 gene in cervical cancers. Int J Oncol 23: 599-604, 2003.

15. Dote H, Toyooka S, Tsukuda K, Yano M, Ouchida M, Doihara H, Suzuki M, Chen H, Hsieh J-T, Gazdar AF and Shimizu N: Aberrant promoter methylation in human DAB2 interactive protein (hDAB2IP) gene in breast cancer. Clin Cancer Res 10: 2082-2089, 2004

16. Baylin SB, Herman JG, Graft JR, Vertino PM and Issa J-P: Alterations in DNA methylation: a fundamental aspect of neoplasia. Adv Cancer Res 72: 141-196, 1998.

17. Ballestar E and Esteller M: The impact of chromatin in human cancer: linking DNA methylation to gene silencing. Carcinogenesis 23: 1103-1109, 2002.

18. Jones PA and Baylin SB: The fundamental role of epigenetic events in cancer. Nat Rev Genet 3: 415-428, 2002.

19. Esteller M: Relevance of DNA methylation in the management ofcancer. Lancet Oncol 4: 351-358, 2003.

20. Hermeking H, Lengauer C, Polyak K, He TC, Zhang L, Thiagalingam S, Kinzler KW and Vogelstein B: 14-2-2 sigma is a p53-regulated inhibitor of G2/M progression. Mol Cell 1: 3-11, 1997.

21. Leffers H, Madsen P, Rasmussen HH, Honoré B, Andersen AH, Walbum E, Vandekerckhove J and Celis JE: Molecular cloning and expression of the transformation sensitive epithelium marker stratifin. A member of a protein family that has been involved in the protein kinase $\mathrm{C}$ signalling pathway. J Mol Biol 231: 982-998, 1993 .

22. Toyoshima F, Moriguchi T, Wada A, Fukuda M and Nishida E: Nuclear export of cyclin B1 and its possible role in the DNA damage-induced G2 checkpoint. EMBO J 17: 2728-2735, 1998.

23. Jin P, Hardy S and Morgan DO: Nuclear localization of cyclin B1 controls mitotic entry after DNA damage. J Cell Biol 141: 875-885, 1998.

24. Prasad GL, Valverius EM, McDuffie E and Cooper HL: Complementary DNA cloning of a novel epithelial cell marker protein, HME1, that may be down-regulated in neoplastic mammary calls. Cell Growth Differ 3: 507-513, 1992.

25. Dellambra E, Patrone M, Sparatore B, Negri A, Ceciliani F, Bondanza S, Molina F, Cancedda FD and de Luca M: Stratifin, a keratinocyte specific 14-3-3 protein, harbours a pleckstrin homology $(\mathrm{PH})$ domain and enhances protein kinase $\mathrm{C}$ activity. J Cell Sci 108: 3569-3579, 1995.

26. Umbricht CB, Evron E, Gabrielson E, Ferguson A, Marks J and Sukumar S: Hypermethylation of 14-3-3 sigma (stratifin) is an early event in breast cancer. Oncogene 20: 3348-3353, 2001.

27. Iwata N, Yamamoto H, Sasaki S, Itoh F, Suzuki H, Kikuchi T, Kaneto H, Iku S, Ozeki I, Karino Y, Satoh T, Toyota J, Satoh M, Endo T and Imai K: Frequent hypermethylation of $\mathrm{CpG}$ island and loss of expression of the 14-3-3 sigma gene in human hepatocellular carcinoma. Oncogene 19: 5298-5302, 2000.

28. Suzuki H, Itoh F, Toyota M, Kikucki T, Kakiuchi H and Imai K: Inactivation of the 14-3-3 sigma gene is associated with $5^{\prime} \mathrm{CpG}$ island hypermethylation in human cancers. Cancer Res 60: 4353-4357, 2000.

29. Gasco M, Bell AK, Heath V, Sullivan A, Smith P, Hiller L, Yulug I, Numico G, Merlano M, Farrell PJ, Tavassoli M, Gusterson B and Crook T: Epigenetic inactivation of 14-3-3 sigma in oral carcinoma: association with p16INK4a silencing and human papilloma virus negativity. Cancer Res 62: 2072-2076, 2002.

30. Kaneuchi M, Sasaki M, Tanaka Y, Shiina H, Verma M, Ebina Y, Nomura E, Yamamoto R, Sakuragi N and Dahiya R: Expression and methylation status of 14-3-3 sigma gene can characterize the different histological features of ovarian cancer. Biochem Biophys Res Commun 316: 1156-1162, 2004.

31. Cho B, Lim Y, Lee DY, Park SY, Lee H, Kim WH, Yang H, Bang YJ and Yeoung DI: Identification and characterization of a novel cancer/testis antigen gene CAGE. Biochem Biophys Res Commun 292: 715-726, 2002.

32. Scanlan MJ, Gure AO, Jungbluth AA, Old LJ and Chen YT: Cancer/testis antigens: an expanding family of targets for cancer immunotherapy. Immunol Rev 188: 22-32, 2002. 
33. Park S, Lim Y, Lee D, Cho B, Bang YJ, Sung S, Kim HY, Kim DK, Lee YS, Song YW and Yeoung DI: Identification and characterization of a novel cancer/testis antigen gene CAGE-1. Biochim Biophys Acta 1625: 173-182, 2003.

34. Chen YT, Scanlan MJ, Sahin U, Türeci Ö, Gure AO, Tsang S, Williamson B, Stockert E, Pfreundschuh H and Old LJ: A testicular antigen aberrantly expressed in human cancers detected by autologous antibody screening. Proc Natl Acad Sci USA 94: 1914-1918, 1977.

35. Jungbluth AA, Chen YT, Stockert E, Busam KJ, Kolb D, Iversen $\mathrm{K}$, Coplan $\mathrm{K}$, Williamson B, Altorki $\mathrm{N}$ and Old LJ: Immunohistochemical analysis of NY-ESO-1 antigen expression in normal and malignant human tissues. Int J Cancer 92: 856-860, 2001.

36. Gaudet F, Hodgson JG, Eden A, Jackson-Grusby L, Dausman J, Gray JW, Leonhardt H and Jaenisch R: Induction of tumors in mice by genomic hypomethylation. Science 300: 489-492, 2003.

37. Eden A, Gaudet F, Waghmare A and Jaenisch R: Chromosomal instability and tumors promoted DNA hypomethylation. Science 300: 455, 2003 .

38. Resnick MB, Sabo E, Kondratev S, Kerner H, Spagnoli GC and Yakirevich E: Cancer-testis antigen expression in uterine malignancies with an emphasis on carcinosarcomas and papillary serous carcinomas. Int J Cancer 101: 190-195, 2002.

39. Razani B, Woodman SE and Lisanti MP: Caveolae: from cell biology to animal physiology. Pharmacol Rev 54: 431-467, 2002.

40. Suzuoki M, Miyamoto M, Kato K, Hiraoka K, Oshikiri T, Nakakubo Y, Fukunaga H, Shichinohe T, Shinohara T, Itoh T, Kondo S and Katoh H: Impact of caveolin-1 expression on prognosis of pancreatic ductal adenocarcinoma. Br J Cancer 87: 1140-1144, 2002.

41. Campbell L, Gumbleton M and Griffiths DFR: Caveolin-1 overexpression predicts poor disease-free survival of patients with clinically confined renal cell carcinoma. Br J Cancer 89: 1909-1913, 2003.

42. Yang G, Truong LD, Wheeler TM and Thompson TC: Caveolin-1 expression in clinically confined human prostate cancer: a novel prognostic marker. Cancer Res 59: 5719-5723, 1999.
43. Ho C-C, Huang P-H, Huang H-Y, Chen Y-H, Yang P-C and Hsu S-M: Up-regulated cavolin-1 accentuates the metastasis capability of lung adenocarcinomas by inducing filopodia formation. Am J Pathol 161: 1647-1656, 2002.

44. Fine SW, Lisanti MP, Galbiati F and Li M: Elevated expression of caveolin-1 in adenocarcinomas of the colon. Am J Clin Pathol 115: 719-724, 2001.

45. Ito Y, Yoshida H, Nakano K, Kobayashi K, Yokozawa T, Hirai K, Matsuzuka F, Matsuura N, Kakudo K, Kuma K and Miyauchi A: Caveolin-1 overexpression is an early event in the progression of papillary carcinoma of the thyreoid. Br J Cancer 86: 912-916, 2002.

46. Wiechen K, Diatchenko L, Agoulnik A, Scharff KM, Schober H, Arlt K, Zhumabayeva B, Siebert PD, Dietel M, Schäfer R and Sers C: Caveolin-1 is down-regulated in human ovarian carcinoma and acts as a candidate tumor suppressor gene. Am J Pathol 159: 1635-1643, 2001

47. Sada K, Takano T, Yanagi S and Yamamura H: Structure and function of SYK protein-tyrosine kinase. J Biochem 130: 177-186, 2001.

48. Yuan Y, Mendez R, Sahin A and Dai JL: Hypermethylation leads to silencing of the SYK gene in human breast cancer. Cancer Res 61: 5558-5561, 2001.

49. Xu X-X, Yi T, Tang B and Lambeth JD: Disabled-2 (Dab2) is an SH3 domain-binding partner of Grb2. Oncogene 16: 1561-1569, 1998

50. Zhou J and Hsieh J-T: The inhibitory role of DOC-2/DAB2 in growth factor receptor-mediated signal cascade. J Biol Chem 276: 27793-27798, 2001

51. Yano M, Toyooka S, Tsukada K, Dote H, Ouchida M, Ave M, Hanabata T, Date H, Gazdar AF and Shimizu N: Aberrant promoter methylation of human DAB2 interactive protein (hDAB2IP) gene in lung cancers. Int J Cancer 113: 59-66, 2005.

52. Wang Z, Tseng C-P, Pong R-C, Chen H, McConnell JD, Navone $\mathrm{N}$ and Hsieh J-T: The mechanism of growth-inhibitory effect of DOC-2/DAB2 in prostate cancer. J Biol Chem 277: 12622-12631, 2002

53. Chen H, Pong R-C, Wang Z and Hsieh J-T: Differential regulation of the human gene DAB2IP in normal and malignant prostatic epithelia: cloning and characterization. Genomics 79 : 573-581, 2002

54. Fazili Z, Sun W, Mittelstaedt S, Cohen C and Xu X-X: Disabled-2 inactivation is an early step in ovarian tumorigenicity. Oncogene 18: 3104-3113, 1999. 